\title{
The Urgency of Vocational Higher Education to Restore the Magnificence of 'Pasar Rakyat' in Indonesia
}

\section{Sri Rahayu and Akbar Nikmatullah Dachlan²}

${ }^{1}$ Vocational Higher Education, Universitas Indonesia, Depok, Indonesia

${ }^{2}$ Faculty of Economics and Business, University of Pertamina, Jakarta, Indonesia

\section{Abstract}

Framing analysis offers a way to describe the power of a communicating text. This study tries to utilize that to synthesize the urgency of vocational higher education to restore the magnificence of 'Pasar Rakyat' in Indonesia. Especially, in terms of community market management. This research will use framing analytical method, put forward by Robert N. Entman, on the news in various digital mass media from January to February 2017. The framing analysis will be done with four framing components,

Corresponding Author:

Sri Rahayu

Sri.rahayu@vokasi.ui.ac.id

Received: 8 June 2018

Accepted: 17 July 2018

Published: 8 August 2018

Publishing services provided by Knowledge E

(c) Sri Rahayu and Akbar Nikmatullah Dachlan. This article is distributed under the terms of the Creative Commons

Attribution License, which permits unrestricted use and redistribution provided that the original author and source are credited.

Selection and Peer-review under the responsibility of the 2 nd ICVHE Conference Committee. namely: (1) problem identification, which emphasizes why vocational higher education can restore the glory of Pasar Rakyat in Indonesia; (2) causal interpretation, what and who should be targeted by vocational higher education in this effort; (3) moral evaluation, related to the ideal character that must be strived to emerge from the manager of 'pasar rakyat'; and (4) treatment recommendation, which emphasizes that vocational higher education can restore the magnificence of the Pasar Rakyat in Indonesia. This research is expected to contribute in the form of the potential of management of 'pasar rakyat' as future skills that can be developed in vocational higher education. So that the standardization of community market management is evenly spread throughout Indonesia.

Keywords: framing analysis, pasar rakyat, vocational higher education, revitalization

\section{Introduction}

Markets are economic institutions where buyers and sellers meet, both directly and indirectly, to perform trade transactions. Based on Law No. 7 Year 2014 on Trade, the term Pasar Rakyat is to replace the term Traditional Market. In the Law, the definition of Pasar Rakyat is a certain area where buyers and sellers meet, both directly and indirectly, by buying and selling various types of consumer goods through bargaining.

Pasar Rakyat offers strategic functions as the knot of local economic strength, conS OPEN ACCESS tributing to the regional economy, increasing employment opportunities, providing 
sales facilities, referencing the price of basic commodities, increasing the Local Revenue (PAD) as the upper stream and the estuary of the informal economy. Responding to these strategic functions, the government seeks to maintain the existence of pasar rakyat by conducting various revitalization programs to prevent the eroding of pasar rakyat from the rapid growth of modern market.

Revitalization is an attempt to revitalize an area or part of the city that was once vital/alive, but suffering from decline/degradation [1]. The revitalization scale has macro and micro levels. In the macro level of revitalization, it is expected to reach the economic and social aspects, while in micro level, revitalization is expected to optimize physical aspects able to recognize and exploit the potential of environment (history, meaning, uniqueness of location and image of place) $[1,2]$.

Indonesian Government through the Regulation of the Minister of Trade no. 61/MDAG/PER/8/2015 on the Development and Management of Trade Facilities, has set guidelines for revitalizing traditional markets or pasar rakyat by prioritizing four principles. These principles are related to physical revitalization, management revitalization, socio-cultural revitalization, and revitalization approach based on Indonesian National Standard (SNI) 8152: 2015 on Pasar Rakyat.

Physical revitalization includes the repair and improvement of the quality and physical conditions, the green system, interface system, a system of signs/billboards and open space areas (urban realm) of 'pasar rakyat'. It also includes the zoning system of the commodities zone (e.g., fish, meat) and dry commodities zone (e.g., vegetables), and so on [4].

Management revitalization is intended to focus on how the management can run 'pasar rakyat' professionally. This includes the availability of standard operating procedures (SOP) on how to collect levies, how to maintain facilities and infrastructure, enhancing the security system, cleanliness, availability of clean water and electricity, as well as the loading area and allocated parking [4].

Social revitalization is how the management of the traditional market can maintain the social life surrounding 'pasar rakyat' environment, also be able to provide good government of 'pasar rakyat', hoping that it will provide a secure, orderly, and comfort location to shop for daily needs [4].

Whereas in SNI of Pasar Rakyat, it is mentioned that the management principles of pasar rakyat are efficient in the use of resources, effective in operational activities, productive in increasing the merchants' income, and accountable in administrative, technical, and financial management. 
In the period of the President Joko Widodo (Jokowi), the revitalization of pasar rakyat has been intensified. This is stated in Nawacita stating that there will be revitalization of 5,000 traditional markets until 2019. In 2015, the realization of Nawacita concerning the revitalization of traditional markets gives blue report cards. The revitalization of pasar rakyat reached 98.52 percent of the target, which was to revitalize 1,002 markets in a year.

Nevertheless, there is an important record of the revitalization of pasar rakyat; market development does not merely improve the condition of physical development. It also touches other aspects such as socio-cultural and governance (management). This is in accordance with the results of the research stating that the development of management and social markets provides positive effects on the performance of pasar rakyat [4].

Improvement of physical condition shall be easier for the government in implementing it if the government budget is available. However, it is not in line with the improvement of social aspects and governance (management). Indeed, it takes time to change stakeholder's behavior, mindset, as well as culture regarding pasar rakyat.

Therefore, the government has made various efforts to change pasar rakyat stakeholders' mindset by, among others, stipulating the guidelines of traditional market revitalization in the Regulation of the Minister of Trade No. 61/M-DAG/PER/8/2015 on the Development of Trade Facilities. One of the principles in the revitalization is in the aspects of management (governance), that is the effort to create professional, modern, and transparent management of pasar rakyat.

This aspect is important considering the advantages of modern market compared to the pasar rakyat which one of them is management. Traders services in the modern market are very concerned about management to attract consumers. On the other hand, physical development done so far, if it is not accompanied by changes in management by market managers, will not be beneficial.

Efforts to change the mindset of stakeholders of pasar rakyat have been intensified by the Government of Indonesia delivered directly by President Jokowi, as well as through the Minister of Trade of the Republic of Indonesia. Both printed and digital mass media have delivered news related to pasar rakyat concluding to the importance of formal education institutions focusing on having certified graduates with skills in market management, at least at the level of Diploma 1. 


\section{Research Background and Objective}

Mass media is essentially a media of public discussion on a problem involving three parties: journalists, news sources, and public in general [5]. The three parties base their involvement on their respective social roles and the relationships between them are shaped through the operationalization of the issues they develop.

Dedy Mulyana in his writings Framing Analysis An Introduction, in Eriyanto (2002) explains that news in newspapers is a way to create the desired reality of a reported event or group. Having passed through the process of selection and reproduction, news in newspapers is an artificial report of an event, but can be claimed as an objective by the newspaper to achieve ideological (and business) aims of the newspaper.

In other words, news in newspaper is not merely conveying, but also creating meaning [7]. This is what makes the process of news formation is a complicated process and many factors have the potential to influence it, that there will be a struggle in understanding the reality. In the presentation, the choice of media is basically the accumulation of various influences.

Therefore, this research seeks to construct the framework and trend of public news on pasar rakyat, especially those leading to the urgency of vocational higher education to restore the magnificence of 'Pasar Rakyat' in Indonesia in terms of management of pasar rakyat.

\section{Methodology}

The paradigm used in this research is constructivist paradigm. According to the constructivist paradigm, the data is 'subjective' in the sense of being based on the views of the parties examined. Subjects examined are treated as research subjects having a view of what the researcher is concerned about. Thus, the data in the constructivist paradigm must reflect 'what is felt and what the researcher wants to convey', not what the researcher wants to tell. Hence, in this research, researchers should explore (embody) the minds of the subjects of research to obtain subjective perspectives [8]. In this research, the researcher performs the analysis of empathic text with framing analysis technique in which the researcher sees the text as produced by the creator/text creator. The data studied are news texts analyzed from what written by journalists.

In maintaining the quality of this research, in accordance with the goodness/quality criteria, constructivist paradigm uses Trustworthiness, that is, researchers believe the 
news written by journalists from the eyes of journalists; and Authenticity, that is, researchers see what the journalists write as it is.

This study uses a qualitative perspective, where one of the important objectives of qualitative research is the acquisition of a thorough and whole understanding of the phenomena studied. This qualitative perspective also sees social phenomena as dynamic and evolving and not as something that does not change in the development of time and conditions. There are at least 8 methods of Qualitative research (Denzin and Lincoln, 1994 and 2000 and their differences for both editions). They generally have a grounded-inductive mindset, that is, an attempt to understand a phenomenon from a theory/concept perspective. Here, concepts are not to be tested/measured in a sample, but rather used to explain the phenomenon being studied. The researcher thus has previously no supposition (a posteriori); he tries to find the 'theory' of the symptoms being studied. The widely used vocabularies include 'interrelationship between symptoms', 'the meaning of a symptom' and 'patterns found' [8].

In a qualitative tradition, even every research method has a way of speaking that is not just to differentiate between types of research methods, but it reflects the basic logic used and the type of findings for each method. Arthur Asa Berger mapped four approaches in analyzing media texts, namely Semiotic Analysis, Marxist Analysis, Psychoanalytic Criticism, and Sociological Analysis [9].

Framing Analysis is one of the methods in Discourse Analysis that has its own 'way of thinking' even though it has a common ground in general that is to pay attention to sign and the meaning of sign; but the ways and forms of findings differ from one another. If it refers to four approaches mapped by Asa Berger, then the framing analysis goes into Semiotic Analysis, because the basis of semiotic analysis is the sign and the meaning of sign [9].

In the framing analysis of this news texts, sentences written by journalists will be analyzed as signs and the meaning of the sentences as meaning of the signs.

This research will use framing analysis method. The first thing to do in framing analysis is to see how the media construct reality. Events are understood not as something taken for granted. On the contrary, journalists and medias are the ones who actively shape the reality.

Reality is created in the conception of journalists. Events, facts, and people, are abstracted into an event that is then presented to the public. Thus, in the framing research, the main issue is how the media constructs the reality/event. More specifically, it is how the media frames events in a construction. Hence, the point of attention 
here is not whether the media present the news positively or negatively but the frames developed by the media.

The method of data collection is to select the unit of analysis from the mass media coverage on the urgency of vocational higher education to restore the magnificence of 'Pasar Rakyat' in Indonesia. Thus, the analysis units developed in this research are: (1) news about government efforts to restore the magnificence of pasar rakyat, and (2) the role of vocational higher education in supporting the effort. The news that will be analyzed are the news from January to February 2017 in various digital mass media as follows: ksp.go.id., bisnis.liputan6.com., kompas.com., republika.co.id., and metrotvnews.com. The choice of digital media is not based on media ownership, but rather on the appropriateness of the reporting with the research context. Thus, this study does not consider the influence of media ownership in framing the news that occurs.

Data to be analyzed are all news related to the urgency of vocational higher education to restore the magnificence of 'Pasar Rakyat' in Indonesia. Analysis technique that will be used to analyze the news in Kompas Daily is framing analysis model from Robert N. Entman (1993). In analyzing a news, Entman proposes four framing components, that is,

1. Problem Identification, which is the first element we can see through framing. It is the most important master frame, and it emphasizes how events are understood. The same event can be understood differently. Different frames will form different realities. Problem Identification in this research will be emphasized in the context of why vocational higher education can restore the magnificence of Pasar Rakyat in Indonesia.

2. Causal Interpretation, which predicts the cause of the problem. It is framing element to frame who will be the actor of an event. In this case, the case can be either 'what' or 'who'. When applied in this research, the emphasis is on what and who should be targeted by vocational higher education to restore the magnificence of Pasar Rakyat in Indonesia.

3. Moral Evaluation, which is to make moral choices. It is a framing element used to justify/argue for defining a problem already created. When the problem has been identified, the cause of the problem has also been identified; it needs argumentation to support the idea. The moral evaluation component is generally used to analyze the moral-related reporting of the subject. Therefore, this research will 
emphasize the moral evaluation aspect on the ideal character that must be sought to emerge from pasar rakyat managers.

4. Treatment Recommendation, which emphasizes on problem solving. In the context of this research, it will emphasize on how vocational higher education can restore the magnificence of Pasar Rakyat in Indonesia.

\section{Results and Discussion}

The analysis unit of mass media reporting on the urgency of vocational higher education to restore the magnificence of 'Pasar Rakyat' in Indonesia, in this research, consists of two, namely: (1) news about the government's efforts to restore the magnificence of pasar rakyat, and (2) the role of vocational higher education in support of such efforts. The news that will be analyzed is the news from January to February 2017 in various digital mass media as follows: ksp.go.id., bisnis.liputan6.com., kompas.com., republika.co.id., and metrotvnews.com.

Following is the categorization of news from various digital mass media based on the two units of the analysis:

1. The news of the government's efforts to restore the magnificence of pasar rakyat. The news collected related to the unit of analysis are:

(a) ksp.go.id, stating that:

President entrusts messages related to the advancement of populist traditional market. He requests the existing people market to be fostered to compete with other modern markets.

(b) republika.co.id

We are developing the market from Sabang to Merauke. Our target is 5,000 in five years. It is indeed a lot, 5,000, but that is our target." If we do not target it, pasar rakyat will be defeated by modern markets, malls, supermarkets, hypermarkets. And of course, I do not hope so -Jokowi.

2. The role of vocational higher education in support of efforts to restore the magnificence of pasar rakyat.

The news collected related to the unit of analysis are:

(a) ksp.go.id, stating that:

If the physical has been restored, please continue to the second stage. Their management and capital shall be assisted and guided. 
(b) bisnis.liputan6.com, stating that:

In addition to physical development and revitalization, Enggar said, Jokowi also wants the government to make improvements on the merchant management. Be it stock management, financial management, layout of goods and others.

For pasar rakyat, Mr. President has ordered not only the physical but also the management of market merchants.

(c) kompas.com, stating that:

The Ministry of Trade shall not only revitalize slum pasar rakyat, but also pay attention to the merchants. Stock management, simple bookkeeping, how to serve buyers, and uniforms for sellers are also the President's mandate.

(d) kompas.com, stating that:

In addition to physical improvements, Jokowi assesses that management improvements are also needed. Jokowi has requested that the officials of the Ministry of Trade present to go directly to the field to guide the merchants.

(e) republika.co.id, states that:

The Minister of Trade, Enggartiasto Lukita, said that in the future the government does not want to only build the physical market, but also provide guidance to the market managers. He said that currently, the center of education and training (Pusdiklat) of the Ministry of Trade is preparing a curriculum for a 'school' of market management. 'Market managers will take short courses on management, including financial statements establishment', Enggar said.

(f) metrotvnews, stating that:

The government is also working on a market classification of the building side, as well as planning to make the basics of market governance (management). The government has targeted to establish a formal educational institution that specifically forms graduates with expertise in certified market management at least at the level of Diploma 1.

The results of framing the news in digital mass media collected, it can be concluded that the Government of Indonesia, especially the Government of President Jokowi shows a 'populist' politic. Jokowi shows his consistency in supporting the development of traditional markets. And he does not stop there. He also thinks on managerial aspect to create not only a pasar rakyat able to compete with modern market, but also performs a good management.

President Jokowi, in the next five years, since elected as the 7 th President of Indonesia in 2014, has targeted to develop500o (five thousand) markets from Sabang to 
Merauke, in five years 5,000. It can be seen as a restoration of the magnificence of pasar rakyat in Indonesia.

In addition, the government also ensures that this magnificence is not only supported by physical factors but governance and social factors, thus the importance of emphasizing management education, from education in the form of market schools, to formal education specifically issuing graduates with expertise in certified market management at least at Diploma 1 level.

In the realization of certification of pasar rakyat management, there are some aspects of management revitalization that need to be the attention of market managers and assisted by the government. First, managerial, financial, and service aspects. So far, financial records in the public market show no transparent and accountable standardization resulting to market revenue that is not maximal.

In addition, service aspects can be further translated as aspects of $\mathrm{K}_{3}$ (cleanliness, orderliness, and security). When visiting pasar rakyat, this aspect has been neglected. Although the construction of the building has been realized, regular maintenance in certain pasar rakyat has not been considered. In addition, the security of physical assets is still not optimally empowered that pasar rakyat is very vulnerable to fire.

In the end, if the government along with the central government and market managers consider the managerial aspect, it is possible that pasar rakyat can compete with the modern markets.

It is at this point that the urgency of vocational education emerges as an effort to improve management or governance in a concrete manner. Vocational higher education based on competence is one of the translation of the formal education institution able to issue graduates with specific and certified competences and skills.

It is hoped that the government will not only pay attention to the physical improvement aspects of pasar rakyat but also the managerial aspect. People shall also be given the freedom to choose their purchase. However, if pasar rakyat can be the market that gives a good service a supporting physical aspect, it is possible that pasar rakyat will find back its magnificence.

\section{Funding}

This study is the continuation of previous studies on the role of revitalization to the traditional market performance. The study was conducted at the end of 2012 and funded by the Ministry of Trade of the Republic of Indonesia. The results of previous studies 
have also been presented in international seminars in an article entitled 'Revitalization of traditional market as an effort to strengthen local economy'.

\section{References}

[1] Danisworo, 2002 understanding revitalization, (online) http://makalahdanskripsi. blogspot.com/2009.03/definisi-revitalisasi.html

[2] Center for Domestic Trade Policy, Trade and Policy Development and Development Agency, Ministry of Trade of the Republic of Indonesia. (2012). Peran Revitalisasi Terhadap Kinerja Pasar Tradisional.

[3] Badan Standardisasi Nasional. (2015). Indonesian National Standard (SNI) 8152: 2015 on Pasar Rakyat.

[4] Rahayu, Sri., Widayanti, Tjahya. (2014). Revitalization of Traditional Market as an Effort to Strengthen Local Economy. The gth International Conference on Business and Management Research.

[5] Nugroho, Ben., Eriyanto., Surdiarsis, Frans. 1999). Politik Media Mengemas Berita (Habibi dalam Pemberitaan Kompas Merdeka dan Republika), Institut Studi Arus Informasi, Jakarta. P. 26.

[6] Eriyanto. (2005). Analisis Framing: Konstruksi, Ideologim dan Politik Media. Yogyakarta: LKiS.

[7] Sudibyo, Agus. (2001). Politik Media dan Pertarungan Wacana, LKIS, Yogyakarta, 2001, p. 7.

[8] Hamad, Ibnu (2005). Membumikan Kriteria Kualitas Penelitian. Jurnal Thesis, 1-6.

[9] Berger, Arthur A. (2005). Media Analysis Technique. Thousand Oaks: Sage Paublications.

[10] http://ksp.go.id/buka-rapat-kerja-kementerian-perdagangan-presiden-jokowiperubahan-itu-dimulai-dari-kita/

[11] http://www.republika.co.id/berita/ekonomi/makro/17/01/30/okkyr7382-jokowisaya-tak-mau-pasar-rakyat-kalah-dengan-pasar-modern

[12] http://bisnis.liputan6.com/read/2864314/kemendag-bangun-dan-revitalisasi1003-pasar-tradisional-di-2017

[13] http://bisniskeuangan.kompas.com/read/2017/02/21/210000926/raker. kemendag.tata.ulang.perdagangan.dengan.paradigma.baru

[14] http://nasional.kompas.com/read/2017/02/21/12033741/jokowi.pasar.tradisional. harus.bersih.tidak.becek.dan.bau 
[15] http://www.republika.co.id/berita/ekonomi/makro/17/02/21/olpuuf382pengelola-pasar-rakyat-akan-diminta-kursus-manajemen

[16] http://ekonomi.metrotvnews.com/mikro/5b27Lgek-kemendag-siapkanstandardisasi-desain-pasar-rakyat 